\title{
School Leadership in Improving the Quality of Education at Integrated Islamic SMP Nurul Fadillah Deli Serdang
}

\author{
Adlin Damainik ${ }^{1}$, Ika Muntazah ${ }^{2}$ \\ ${ }^{1,2}$ Universitas Islam Negeri Sumatera Utara, Indonesia \\ adlindamanik@uinsu.ac.id
}

\section{Abstract}

This study aims to determine the principal's leadership in improving the quality of SMP IT Nurul Fadhillah, the constraints of the principal's leadership in improving the quality of schools at SMP IT Nurul Fadhilah, and the principal's efforts to improve the quality of schools at SMP IT Nurul Fadhilah. The method used in this research is qualitative research with a descriptive approach and the techniques used are observation, interviews and documentation. The subjects of this study were the principal and teachers. Data analysis techniques use data reduction, data presentation and conclusions. Ensuring the validity of research data uses credibility, transfibility, dependability and conformability. The results of this research are the principal's leadership in improving the quality of education by caring for subordinates, assertiveness, democracy, and supervision. The obstacles faced by school principals in improving the quality of schools are the lack of educational facilities and infrastructure. As for the efforts made by the principal in improving the quality of education, namely developing teacher competence, meeting the needs of school stakeholders and getting used to working together in overcoming problems.

Keywords leadership; principal; school quality

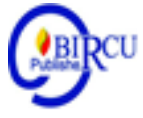

\section{Introduction}

Education is a factor that plays a role in the intellectual life of the nation. This is in line with the formulation of the goals and functions of national education as stated in the Law on the National education system Number 20 of 2003 article 3 which reads: national education has the function of developing capabilities and is in the form of dignified national character and civilization in order to educate the life of the nation, aimed at developing it. the potential of students to become human beings who believe and fear one God, have noble character, are healthy, knowledgeable, capable, creative, independent, and become democratic citizens ( RI Law No. 20 of 2003 ).

Education is not a complementary life that can only be needed from time to time, but a major need that touches all aspects of life. Education plays a very important role in the process of improving human resources, improving the quality of education is a process that is interacted with the process of improving the quality of human resources itself. The reality is that at the national, provincial, district level, even up to school units, the improvement in the quality of education is felt to be uneven. The element of equal distribution of quality improvement should contain 8 standards, namely, content standards, process standards, teaching staff standards, education personnel, management standards, cost standards, facilities and infrastructure standards, graduate standards, and evaluation 
standards, the achievement and improvement of standardization are strongly influenced by competence. Educators and education staff (Rusli Yusuf: 2009).

Education is a systematic learning process, used to create a learning system so that students are able to develop their potential.

According to Martinis Yamin, and Maisah (2010: 26). National education which is based on Pancasila and the 1945 constitution of the Republic of Indonesia functions to develop capabilities and shape the character and character of the nation with dignity in the context of the intellectual life of the nation, aims to develop the potential of students to become human beings who believe and fear an almighty God. , have noble character, healthy, knowledgeable, competent, creative, independent, and become democratic and responsible citizens.

Syafaruddin, and Asrul (2013: 87) Education is a human thing that is the key to sustainable development and peace in all countries, especially anticipating global dynamics, so the empowerment of human resources through education is a key word that should not be ignored at all, except for nations feeling inferior in facing the progress of this national education era is an integral education with a focus on fostering personal, spiritual and intellectual potential as well as social potential.

Quality of education can be achieved if all components of education meet the requirements. Of the several components of education, the most important role is the principal. Principals who succeed when they understand the existence of the school as a complex and unique organization and are able to carry out the role of the principal as someone who is given the responsibility to lead the school. Handling the educational problem is a system, because it can only be carried out completely if it is carried out by all its components through a reciprocal and comprehensive relationship. In other words, all components of the education system (family, educational bureaucracy, schools, society and the mass media) must be actively involved in it and not run independently. So the principal success study shows that the principal is someone who determines the center point and rhythm of a school. There are two important things from this formulation, namely (1) the principal as a central force that is the driving force of school life (2) The principal must understand their duties and functions for the success of the school, the requirements for having concern for staff and students (Yusuf Hadijaya : $2012: 33$ ).

These two formulations are the key to the success of the principal's leadership in improving the quality of education in the schools they lead, but they are not an absolute guarantee. However, it does not mean that all of these must be completely owned by a school principal as a leader, but this is a requirement that must be owned by the principal in an effort to carry out his leadership to improve the quality of education (Nurhaya : 2017; 2).

Based on the results of preliminary observations at SMP IT Nurul Fadhillah the principal in empowering teachers, administrators and students by motivating and giving high confidence to teachers, administrators and students in carrying out their duties. Teachers are assigned according to their fields. Assignments to teachers who accompany tutoring in preparation for the subjects being tested are carried out earlier. The principal has a lot of trust in his representatives. Administration works in accordance with what is assigned to it, in order to help smooth the administration required by teachers in schools. Meanwhile students are always encouraged to study harder, but the backgrounds of students who entered the Nurul Fadhillah Islamic Integrated Middle School are not academically selected, so it is not easy to expect good results. There are steps taken by the principal in an effort to improve the quality of the school, but the implementation is less 
controlled. The principal delegates that control to his deputy. Not all of the evaluations were carried out. With the lack of control from the school principal, and not all assignments are evaluated, there is little influence on the efforts made to improve school achievement. The principal of the school is more devolved downward.

Education has a strategic role in advanced times, the excellence of a nation is not only relying on natural resources but on the advantages of human resources (HR). The quality of human resources (HR) is determined by the quality of education, benchmarks for the quality of education are based on conditions of output and outcome that meet the requirements in facing the demands of the times. To realize the quality of education, it must be supported by an adequate education component. These components become input (input) to be processed so as to produce superior output (output) and outcome (impact).

Mulyasa in Sudarti (2017) suggests that efforts that can be made to improve school performance in the context of empowering educational personnel are: (a) fostering discipline for educational personnel. The principal must be able to foster discipline in the education staff, especially self-discipline. (b) providing motivation. Motivation is a dominant factor and can move other factors towards work effectiveness. Motivation serves as a driving force and direction. (c) rewards. Rewards are very important to increase work productivity and to reduce activities that are less productive. Through rewards, educational staff are stimulated to increase positive and productive performance. The use of awards needs to be done appropriately, effectively and efficiently so as not to cause negative impacts.

As a manager, the principal must be able to utilize all school resources in order to realize the vision and mission to achieve predetermined goals. In addition, the principal must be able to face various problems at school, think analytically and conceptually and must always strive to become an intermediate teacher in solving various problems faced by the education staff who are his subordinates, and strive to make decisions that are satisfactory for all.

Improving the quality of education (schools) is not easy, to achieve good quality is not always synonymous with the amount of funds spent, the location of schools in villages or cities, public or private, but it is very much determined by how schools provide quality services to students so that they produce students. quality.

The condition of educational institutions (schools) in our country today still has several classic problems, namely the lack of school facilities and infrastructure, inadequate building conditions, the quality of the teaching staff has not met the competence and policies are less productive. On the other hand, it is very encouraging that there is an increasing public awareness of the importance of quality education.

Quality education is produced by the leadership of quality school principals, quality school principals are professionals. Professional school principals are capable of managing and developing schools comprehensively (thoroughly), therefore the principal has a very important and strategic role in realizing the vision, mission and goals of the school. Professional school principals in carrying out their duties are full of quality improvement strategies, so as to produce quality outputs and outcomes. The professionalism of the principal will show the quality of school performance (Rohiat :2008; 20).

Based on the description, the researcher is interested in knowing how the principal can carry out his leadership, so the author chooses the title "Principal Leadership in Improving the Quality of Education in the Nurul Fadhillah Integrated Islamic Junior High School, located on Jl. Implementation of Gg. Brother IV, Bandar Setia, Kec. Percut Sei Tuan, Kab. Deli Serdang, Prop. North Sumatra. 


\section{Review of Literatures}

Leadership is the nature of the leader in carrying out his duties and obligations as well as his responsibilities morally and legally formally or the entire implementation of his authority that has been delegated to the people he leads. Etymologically, leadership comes from the basic word "pimpin" (lead) which means to guide or guide. Leadership itself is the science and art of influencing people or groups to act as expected in order to achieve goals effectively and efficiently ( Malayu Hasibuan : 2007: 167) . M ccording Handoko in Priyono (2010: 123) leadership is the ability that belongs to someone to influence others in order to work toward goals and objectives. According to P lunkett in Mesiono, leadership is one of five other functions in management. Leading people and organizations requires multi-activity capability. Lunenberg and Orsntein in Risnawati detail the meaning of leadership as follows:

a) Leadership is the process by which the influence of group activities exceeds expectations.

b) Leadership is influencing, guiding and directing cars of activities and opinions.

c) Leadership is effective influence.

d) Leadership is convincing other people to improve their own interests and are willing to accept the goals of a group like his own (Risnawati : 2014;71).

Principal leadership is the ability of the principal to exert influence on others through individual and group interactions as a form of cooperation within the organization to achieve predetermined goals effectively and efficiently. Fauza (2020) Leaders to be successful and functional, timely need to start understanding and acceptance of change and to develop the potential they have, which will contribute to the success of the organization. The implementation of leadership can be successful, the leader must pay attention to several things as follows, namely, the ability of the principal, influencing others, individual and group interactions, cooperation, goals, effective and efficient. Recent initiatives revealed that participations of community members in development activities are influenced by the leadership style exhibited by the community leaders (Adedokun, 2019).

Leadership a person's ability to make others willing to follow. Any organization needs leaders at every level. Whether it is because of the result of the appointment or election, what is clear is that a leader with qualities will be able to find and maintain it, provided that the desired criteria and character really get attention. David Hakala in Sudarwan Danim (2010: 34) suggests 10 quality leadership characters, as follows. Having a vision, integration, dedication, Virtue mind, a low heart, openness, creativity, fairness, firmness, sense of humor. The transformation of the contemporary era school to an integrated quality school begins with a shared commitment to quality education by: school committees, administrators, teachers, staff, students and parents in the school community.

According to Oemar Hamalik in Arbangi (2016: 86), the notion of quality can be seen from two sides, namely the normative and descriptive aspects. In the normative sense, quality is determined based on intrinsic and extrinsic considerations (criteria). Based on intrinsic criteria, the quality of education is an educational product, namely educated humans. According to ideal standards. Based on extrinsic criteria, education is an instrument for educating a trained workforce. In a descriptive sense, quality is determined based on actual conditions, for example the results of learning achievement tests.

In the context of education, the notion of quality includes educational inputs, processes and outputs. Educational input is something that must be available because it is 
needed for a process to take place. Meanwhile, the educational process is changing something into something else. Furthermore, educational output is school performance, namely school performance resulting from school processes and behavior. Therefore, quality in the world of education can be stated as prioritizing the existence of students. In other words, school improvement programs are carried out more creatively and constructively (Aminatul Zahroh: 2014: 32).

\section{Research Methods}

This research was conducted at Nurul Fadillah Integrated Islamic Junior High School at Jalan Gg. Brother IV, Bandar Setia Village, Percut Sei Tuan District, Deli Serdang Regency. This research uses a qualitative approach with descriptive research type. As for the subjects of this research, the Principal of the Integrated Islamic Junior High School Nurul Fadhilah, the deputy principal of the school, teachers and staff. Data collection techniques used in the study was observation, interviews and documentation. Data analysis techniques used include data reduction, data presentation and drawing conclusions. Field notes are collected and analyzed carefully and straightforwardly, then set aside field data that are not in accordance with the data research focus and research discussion. After the data is presented in a series of data analysis, the data is displayed to facilitate drawing conclusions.

\section{Discussion}

\subsection{Leadership of the Principal of SMP-IT Nurul Fadhillah in Improving the Quality of Education}

The leadership of the principal is very important to improve the quality expected by each school. Related to the importance of improving the quality of education in schools and to improve the quality of education, it is seen from the ability of the principal in fostering cooperation with all work climate personalities and increasing the active participation of parents and students.

Assignment as head of the school is as an educator administrator, supervisor, leader, innovator, and motivator. So I as head of the school should be able to fulfill all of the functions that, in order to improve the quality of education.

In improving the quality of education in this school we always work together, for example in developing learning methods we always discuss with other teachers so that the methods used in the classroom are easily understood by students. And the teachers here are also in accordance with their fields so that teachers have no difficulty in providing material to students, this is based on a training program to produce teachers as educators who are skilled in improving quality.

\subsection{Obstacles of the principal in improving the quality of SMP IT Nurul Fadhilah}

Principal said that to improving the quality of education at SMP IT Nurul Fadhilah of course has obstacles. Leadership obstacles from principal perspective in improving the quality of education at SMP IT Nurul Fadhilah are inadequate infrastructure. Constraints in the facilities and infrastructure are the most basic obstacles in improving the quality of education.

In improving the quality of education in schools SMP IT Nurul Fadhillah was certainly there, as for the obstacles that there are means and infrastructures which have not 
been fulfilled, facilities and infrastructures that have not fulfilled this depends on the user . For example, a science teacher wanted to do a practice field in teaching will be but a tool that is used in schools is still lacking, so the practice is not able to do it up .

Improving the quality of education must have obstacles, the facilities and infrastructure are still inadequate, the principal also strives to meet the needs of facilities and infrastructure at school, especially in this case also for teaching and learning activities at school to be carried out effectively and efficiently .

\subsection{The Principal's Efforts to Improve the Quality of Nurul Fadhilah's SMP IT}

The leadership of the SMP IT principal Nurul Fadhilah is seen from her ability to carry out her duties as school manager. The school manager's job is to carry out the maintenance and professional development of teachers. Junior high school principal IT Nurul Fadhilah provide facilities and provide opportunities and wide as possible for teachers in order to carry out the activity profession development with various activities or training undertaken either at school or through education and training outside the school. M Enhancing the quality of teachers in junior IT Nurul Fadhillah in education we will bring speakers from outside to portray their education and learning. In addition to that , if there are activities outside of school and the activities it can develop the quality of education then we will send teachers to follow the activities that, after teachers have completed follow the activities of the then she will be in the request for the realization of what that get, to develop the school 's .

The principal must also be able to meet the needs of school stakeholders. Starting from the teacher, fulfilling teacher needs can be done with supervision, supervision carried out at SMP IT Nurul Fadhilah is carried out in two ways, namely scheduled supervision and unscheduled supervision. Scheduled supervision is carried out at a predetermined time, while unscheduled supervision is carried out by the principal directly without notification to the teacher.

\section{Conclusion}

\subsection{Conclusion}

1. The leadership of the principal in improving the quality of education. By prioritizing cooperation in implementing leadership, to improve the quality of education, making innovations in learning such as providing conceptual learning, improving teacher abilities, placing teachers in accordance with their fields, and carrying out educational supervision.

2. The obstacle faced by the principal of SMP IT Nurul Fadhillah in improving the quality of education is the lack of educational facilities and infrastructure. These educational facilities and infrastructure greatly affect the learning process. For the quality of education will be achieved if the learning process is truly effective and useful for achieving student abilities.

3. The leadership efforts of the headmaster of SMP IT Nurul Fadhilah in improving the quality of education are carried out by developing teacher competencies, meeting the needs of school stakeholders and getting used to working together in overcoming problems. SMP IT Nurul Fadhilah efforts to empower educational personnel in accordance with the activities carried out at school always work together and head The school always develops teacher competence through various activities. 


\subsection{Suggestion}

Based on the above conclusions, the recommendations or suggestions in this study are as follows:

1. For the principal to complete the facilities and infrastructure in the school so that learning is carried out effectively.

2. For teachers, staff, in order to improve their skills evens more for more advanced schools.

3. For readers of this paper, it is hoped that they will care more about and understand improving the quality of schools.

\section{References}

Abdillah. (2010). Peran guru dalam menciptakan sekolah efektif. Jurnal Kependidikan dan Keislaman, XVII (2). pp. 134-143. http://repository.uinsu.ac.id/348/

Abdillah. (2010). Sekolah unggul dan pengendalian mutu pendidikan. Hijri: Jurnal Manajemen Kependidikan dan Keislaman, III (1). pp. 1-13. http://repository.uinsu.ac.id/325/

Adedokun, M.O., Kayodel, G.M. (2019). Local Leadership Styles and Community Development: A Study of the Irasa Community of Ado-Ekiti, Nigeria. Budapest International Research and Critics in Linguistics and Education (BirLE) Journal Vol 2 (4): 27-31.

Danim, Sudarwan. (2010). Kepemimpinan Pendidikan. Alfabeta.

Dakir Umiarso, Arbangi. (2016). Manajemen Mutu Pendidikan. Jakarta: Kencana.

Fauza, H. (2020). The Correlation between Transformational Leadership Styles with Teacher's Performance in SMP Negeri 2 Medan. Budapest International Research and Critics in Linguistics and Education (BirLE) Journal Vol 3 (2): 1164-1169.

Himpunan Perundang-Undangan RI tentang (SIDIKNAS) UU RI No. 20 tahun (2003) beserta penjelasannya. 2008. Bandung: Nuansa Aulia.

Hadijaya, Yusuf. Administrasi Pendidikan, (2012). Medan, Perdana Publishing.

Hasibuan, Malayu. Manajemen Sumberdaya Manusia. (2007). Jakarta :Bumi Aksara.

Nurhaya. (2017). Kepemimpinan Kepala Sekolah dalam Meningkatkan Mutu Pendidikan

DI SDN 4 Sungai NIlam Jawai. Jurnal Pendidikan dan Pembelajaran Khatulistiwa, vol 6 No. 11.

Priyono. (2010). Manajemen Sumber Daya Manusia. Surabaya: Zifatama Publishing.

Rohiat. (2008). Kepemimpinan Kepala Sekolah, Bandung: PT Refika Aditama.

Risnawati. (2014). Administrasi dan Supervisi Pendidikan. Yogyakarta: Aswaja Pressindo.

Sudarti, dkk. (2017). Kepemimpinan Kepala sekolah dalam Meningkatkan Mutu Sekolah (Studi Kasus Di SMP Suster Pontianak). Jurnal Pendidikan dan Pembelajaran Khatulistiwa, Vol. 6 No. 12.

Yusuf, Rusli. (2009). Landasan Pendidikan. Darussalam

Yamin, Martinis \& Maisah. (2010). Standarisasi Kinerja Guru. Jakarta:Gaung Persada.

Syafaruddin \& Asrul. (2013). Kepemimpinan Pendidikan Kontemporer. Bandung: CitaPustaka Media.

Zahroh, Aminatul. (2014). Teori \& Praktik untuk Meningkatkan Mutu Pendidikan. Jakarta: Ar-Ruzz Media. 